\title{
SEMIOTICS OF DIGITAL CACOGASTROMANIA
}

\author{
Gabriele Marino \\ University of Turin \\ gabriele.marino@unito.it
}

\begin{abstract}
cucinaremale ("badcooking" or "cookingbadly") is an Italian Facebook group created in 2014 which now (February 2020) counts more than 126,000 members. It was conceived to let members post their everyday culinary disasters and amusingly show solidarity with each other, while struggling in a cruel world where - as the official description suggests - everybody seems to have become a professional cook, capable of distinguishing even the different types of salt on the market: "Enough with this craze for cooking: hurray for pre-cooked food!". The article proposes an analysis of the culinary ideologies at stake and a typology of the textual practices carried out by the cattivicuochi ("badcooks"). cucinaremale provides a true manifesto against the global food craze better known as gastromania - a true cacogastromania ("bad gastromania" or "mania for the bad food").
\end{abstract}

Keywords: facebook groups, food porn, gastromania, semiotics, social media

Digital Age in Semiotics \& Communication, Vol. III-IV, 2020/21, 57-82 


\section{Semiotics on food: Gastromania and \#foodporn}

In recent years, semiotics - and Italian semiotics in particular - has been dealing a lot with food (for a state of the art, see Stano 2016). On the one hand, semiotics has focused on food in a classic ethno-anthropological fashion, namely by considering food and all the related human practices as conceived in a given socio-cultural context (according to a noble tradition dating back to Lévi-Strauss 1964). On the other, it has done so in a classic mediological sense, namely, by seeking to understand the regimes of signification pertinent to the human/food relationship as seen through the lens of the media. In other words, by focusing on the representation of food in magazines, movies, TV programs, and the Internet.

The reason for such an interest is obvious. Food has been at the heart of a true collective obsession: gastromania (see Marrone 2014). The discourse of food has extended its boundaries, it has become intensified, and ubiquitous. Food has stopped being the exclusive prerogative of the gourmet, the refined and elitist connoisseur, and has become the business of groups of foodies, do-it-yourself food enthusiasts of all kinds and for all reasons seeking the latest niche to explore. A structural dimension of human experience and life, one of the chief vehicles of self-representation and affirmation of identity (strictly tied both to religious cults and to the recognition of one's social status), nowadays food has more widely become the fulcrum of individual and collective axiologies (systems of values), as much as sexual, religious, political, and consumer attitudes. It is no coincidence that lifestyles or forms of life such as vegetarianism and veganism (diversely linked to issues of health, ecology, animal rights, ethics, philosophy, science, and politics) have become a growing and increasingly powerful trend in Western countries. The same applies to the rhetorical constructions of "nature" and "naturalness" in their different food and product declinations ("biological", "fair trade", "kilometre zero", "home-made", "traditional" et similia), with haute cuisine to be configured as a "field of tension between nature and culture" (Pozzato 2012: 167; my trans.). At the same time, on the opposite side of the ideological trench, we have witnessed the invention of brand new culinary traditions (see Mangiapane 2015) - oxymoron intended - and the rise of a whole new series of foods and meals; so-called post-food, such as the purely chemical meal replacement Soylent or cultured/in vitro meat.

Food has become a pervasive presence throughout the social media, mainly thanks to the ubiquity granted by mobile-based technologies. It is theoretically possible to imagine a dish being prepared and consumed without being photographed and published on some newsfeed (as a pop- 
ular Internet meme suggests: "What if I told you / You can eat without posting it on Instagram") ${ }^{1}$, but in fact the hashtag \#food ranked $34^{\text {th }}$ on Instagram in 2017, with some 27,409,000 shared pictures (Honigman 2017). Inspired - or, better, influenced - by both superstar (e.g. Michelin Starred Carlo Cracco, to remain in the Italian context) and next-door (popular blog Giallo Zafferano or former anchorwoman Benedetta Parodi) chefs, and pursuing the modes of food photography and food styling (the art of presenting food by applying the canons of fashion and advertising pictures, according to the principle that "presentation is everything"), millions of users all over the world publish fragments of their gastronomic and culinary experiences on a daily basis. They carefully arrange the profilmic material (the ingredients, the food, the meal, the course, the dish), tailor the shot (from above, foreshortening, close up), choose a given effect (or, simply, filter) and a series of hashtags to let the picture enter the discoursive flow of online food with a precise connotation: that of food porn. \#foodporn hashtagged images, about 10,647,000 on Instagram in 2017 (ranked $\left.96^{\text {th }}\right)$, are extremely elaborate, hyper-realistic, vivid, synaesthetic, "yummy" pictures. They pursue one single goal: to make the mouths of those who are watching them water ${ }^{2}$. The case we are about to explore, on the other hand, achieves completely the opposite outcome.

\section{Raw rigatoni is very good: Meet cucinaremale}

On 11 September 2014, I was lazily scrolling down my Facebook newsfeed trying not to read something stupid about the $9 / 11$ anniversary. It was late at night and I was working on my thesis, as happens, I guess, to the average $\mathrm{Ph} . \mathrm{D}$. student. While scrolling and taking notes, my eye was caught by a familiar name posted onto the wall of a never-heard-of-before group. The post read: grazie di avermi accettato nel gruppo. ora vi svelo un segreto: $i$ rigatoni crudi, da sgranocchiare davanti alla $t v$, sono buonissimi ("thanks for accepting me in the group. now I'll tell you a secret: raw rigatoni [a type of pasta], to be munched in front of the TV, is very good"). This Facebook friend of mine was an underground musician I had added years before (I think it was 2010), when I used to systematically add all the musicians I liked, and who pursued the behaviour of the perfect Internet troll (on Facebook, he declares he is living in Trolla, a Norwegian town which to the

\footnotetext{
${ }^{1}$ For a semiotic introduction to so-called online viral contents and Internet memes, see Marino (2015).

${ }^{2}$ Food porn involves a nuance of passivity, since "cooking food and presenting it beautifully" would represent "an act of servitude" for women, "a symbol of a willing and enjoyable participation in servicing others" (Coward 1984: 103).
} 
Italian speaker sounds just like the third person singular - egli/ella trolla; "he/she trolls" - of the verb trollare, "to troll"). That night I discovered cucinaremale (literally, "badcooking, cookingbadly"). And I immediately fell in love with it.

After reading a few posts, I realised that the group proudly stood against all the food craze Zeitgeist. It seemed a very self-aware, self-ironic minority community to me, which is something attractive to a semiotician by definition, I guess. Furthermore, as all my friends and kinfolk may testify, I am no stranger to peculiar food routines (fasting, binging, eating snacks only, etc.). That is why I started a kind of participant observation, posting pictures of some "meals" of mine and interacting with other members, in the attempt to figure out the implicated meaning-making practices. Besides having a lot of fun ${ }^{3}$.

\section{Hurray for the precooked!: cucinaremale in a nutshell}

cucinaremale (fb.com/groups/cucinaremale) is an Italian Facebook group which was created on 12 January 2014 by a single user (along with the collaboration of two friends), now counting more than $126,000^{4}$. The group was conceived to let the members post their everyday culinary disasters and be amusingly supportive towards one another, while struggling in a cruel world where - as the official description suggests - everybody seems to have become professional cooks, capable even of distinguishing the different types of salt on the market: Basta con questa gente [che] ha la passione per la cucina, che distingue tutti i tipi di sale in commercio.. ma il sale dell[']Himalaya chi lo usa? Evviva il precotto! ("enough with these people [who] have a passion for cooking, who distinguish all the types of salt on the market .. but who really uses Himalayan salt? Hurray for the precooked!").

The cover image originally uploaded on 12 October $2014^{5}$ (see Fig. 1; the current one is different but actually remixes the very same elements) displayed the name of the group, along with the caption .....per non parlare

\footnotetext{
${ }^{3}$ A first version of this paper, mainly based on an ethnography conducted between 1-13 October 2014, was published as Marino, G. 2014. Cucinaremale. Semiotica del cibo che fa passare l'appetito. E/C, 03.11.2014. http://www.ec-aiss.it/archivio/ricerca_v.php?parola_ chiave $=$ cucinaremale\&invia $=$ cerca $($ accessed 10 February 2020). The present paper is a considerably revised, extended, and updated version; key integrations were made in 2018 and 2020. Quotations from the group posts, in Italian, are in italic (original typos, misspellings, and mistakes included).

${ }^{4}$ As of 10 February 2020.

${ }^{5}$ https://www.facebook.com/photo.php?fbid=10204603603587247 (accessed 10 February 2020).
} 
di come facciamo le copertine ("[cooking badly] not to mention how [badly] we make the covers"), and the group's logo: the stylization of a pan, seen from above, with a spiral and a superimposed ghost face upon it (probably a reference to the iconic mask of horror film series Scream or its parody, Scary Movie). The spiral seems to mock the coiled "M" of MasterChef, the blockbuster format that popularized cooking competitions on TV, as much as the Slow Food slug (the shade is quite similar, being an opaque orange tending to light brown). The Slow Food movement was founded in 1986 by Carlo Petrini, aimed at promoting enogastronomy as a culture of genuineness and enjoyment.

\section{cucinaremale}

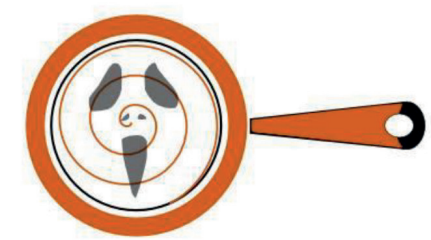

Fig. 1: Cover picture of Italian Facebook group cucinaremale, 12 October 2014 (https://www.facebook.com/photo.php?fbid=10204603603587247, accessed 10 February 2020).

cucinaremale does not oppose the aesthetics of food porn by promoting so-called junk food ${ }^{6}$, since the latter seems to have become just one of the many declinations of the former. Junk food has been globally cleared through customs by social pages such as BuzzFeed Food, FoodBeast, and the Vulgar Chef, thanks to their video recipes (most of them employ industrial food as primary ingredients, also due to their commercial partnerships with food brands). Likewise, the most popular media in the vertical, Tasty, often proposes recipes that the average Italian consumer would be prone to ascribe to the junk food area. TV programs such as Unti e bisunti (lit. "Oily and greasy"), produced by channel DMax Italia (2013-2015) and hosted by former rugby player Chef Rubio (Gabriele Rubini), dedicated to street food, and Snack-off (namely, "Show off with snacks"), produced by MTV (2014-2015), where contenders competed "in the preparation of the most mouth-watering, original, and well presented snack, using strange ingredients such as cookies, chips, and soft drinks"', headed in the same direction. The boom of "kilometre zero" burger joints also helped shorten the distance between the two worlds, reconciling the junk of "fast" (the hamburger format) and the quality of "slow" food (e.g. battuta di fassona,

\footnotetext{
${ }^{6}$ The coinage of the notion of "junk food" is attributed to Jacobson (1972). It designates food that is nutritionally poor, highly caloric, rich in fats, sugars, or salt (such as industrial snacks or fast food items).

7 https://web.archive.org/web/20170129191055/ondemand.mtv.it/serie-tv/snack-off-follieai-fornelli (TV program Snack-off on MTV Italia official webpage, my trans.; accessed 10 February 2020).
} 
"fassone veal tartar"). Although the junk food category is well represented in the group (with a focus on snacks, fried food, and exotic or generically defined "strange" food), cucinaremale rather seems a review of food junk, a collection of failures, of monster-food caught by the camera just before being thrown in the garbage bin or down the toilet. This is food that can be described in many ways: but not as "mouth-watering" at all.

\section{I break spaghetti in half: The cucinaremale community}

Perfectly aware of having created neither meals nor courses but "horrors", "artistic disasters", or "still lifes" at most (nature morte, lit. "dead natures" in Italian), the members of cucinaremale tell their kitchen misadventures via original pictures, brief texts, and comments, looking for their peers' support. cucinaremale is a safe haven for the cattivicuochi ("badcooks"): Sono felicissima d'aver trovato il gruppo giusto $x$ me!!! ("I'm so happy I've found the right group 4 me!"), Ciao a tutti ! Non mi sento più' sola ...... ("Hello everyone! I don't feel alone anymore").

The narration times (see Genette 1972) in cucinaremale are essentially two: the subsequent (when users talk about past episodes and retrieve images from their old folders or memory cards), and the simultaneous (which is the most common one, as it occurs when users post while cooking or just at the end of the process). There are also examples of prior narration, when users anticipate with trepidation that they will soon post some content, prepare something, or do so in the next few days for a particular occasion. Typical narration is first-person and autodiegetic. The badcooks are the protagonists of their own stories. Heterodiegetic narration is limited to members "reporting" friends and relatives' creations and experiences ( $U n$ amico che vuole restare anonimo mi ha mandato questa: melanzana al forno, esplosa, "A friend who wants to remain anonymous sent me this: baked eggplant, exploded") or foods presented elsewhere - inside and outside Facebook - as good but that, according to the community standards, are actually ascribable to the badlycooked genre as well (e.g. "the kitchen $\dot{a}$ la Canalis", cf. infra). Other examples of this kind of content include stock photos, found pictures, or Internet memes, namely non-original material which can be found in the group although its usage is prohibited by policy (summarized in the official group description).

Whereas the badcooks are the narrators and the main characters, it is food, furnished with an agency of its own, that stands as the absolute star under the spotlight, almost entirely filling the figurative universe of the group. This is all about ugly food. Except for what we can see from a few selfies, used to testify the momentum (with the self-portrayed members 
carrying a typical expression of ironic disappointment and guilty satisfaction), the body of the badcook is shown only via Informants such as - often injured - fingers, hands, and arms. Their role is to stress the "autographed", self-made nature of the creations (it is those fingers, hands, and arms that created it all).

cucinaremale is not a Facebook group only. It is a united community where the phatic component is central and constantly revived. badcooks who approach the group for the first time, once their admission has been approved by an administrator or a member, are invited to present themselves with a self-introductory post. They declare their culinary wrongdoing (Faccio outing: spezzo gli spaghetti a metà, "I'll come out: I break spaghetti in half"), or fetishism (Io prendo i tortellini, li sbuccio e il ripieno lo intingo nella maionese, "I take tortellini, peel them and dip the stuffing in mayonnaise"), and post a "specialty" of theirs or their most recent preparation, often inviting the members to guess what kind of stuff it is or should have been (Indovinate almeno tre ingredienti, "Guess at least three ingredients"; cf. infra). The badcooks have their own catchphrases (baaaaaan!), memes (demotivationals, Expectation vs. Reality), icons ("chicken à la Stephen King", "piranha", "ass cake"; cf. infra), polemical totems (the Bimby food processor ${ }^{8}$, Michelin starred chef Carlo Cracco's pizza ${ }^{9}$ ). They even have their own Smurf-like language, starting from their very self-denomination as cucinaremalisti (something like "cookingbadly-ists") and the univerbated word cucinaremale ("cookingbadly") which has substituted the verb cucinare ("to cook") itself (recalling the lexicalization of the verb "I think" as aifinkso in Lolspeak; see Fiorentini 2013). Members create thematic dishes and launch contests for cake design, mug cakes, meringues, pancakes, flans, omelettes, pizza, arancini etc., often on the occasion of holidays such as Easter, Christmas, Halloween, and Valentine's day. They say "good morning" and "good night"10, sometimes putting the gastronomic focus in the background and accessing a purely existential dimension: Non scherzo vi adoro gruppo.. Basta leggere i commenti e vedere le foto per non farmi pensare e fare passare la malinconia...vi lovvo tutti ("I'm not kidding, I adore you group .. Just reading the comments and looking at the pictures

\footnotetext{
${ }^{8}$ Bimby is a noted highly automated food processor, as well as the Opponent/Helper in many cucinaremale tales.

${ }^{9}$ https://www.telegraph.co.uk/news/2018/03/11/italians-turn-michelin-starred-chef-sacri legious-pizza-recipe/ (accessed 10 February 2020).

${ }^{10}$ And the formula buongiornissimo is widely employed, in a self-ironic fashion; it may be translated as something like "good morning-est", namely the morning greeting with the superlative applied not to the adjective but to the noun.
} 
helps me not to think and makes the melancholy go away ... I love you all"; where lovvo is the third person singular of the infinite lovvare, a teenagerish Anglicism from "to love").

The badcooks remain stuck on the group's walls and posts, so that cucinaremale seems to be ascribable to the traditional stickiness model of online content and interaction, rather than to the more up-to-date spreadability one ${ }^{11}$. Members see the group as an environment in which to live and concentrate all their resources: Mio marito mi chiede:l'hai fatto vedere agli altri? [riferendosi a una delle foto pubblicate sul gruppo] Ho omertosamente risposto: 'quello che si pubblica nel cucinaremale, resta nel cucinaremale' ("My husband asks me: have you shown it to others? [referring to one of the photos published in the group] I replied cryptically: 'what is published in cucinaremale, remains in cucinaremale"). In other words, the badcooks do not share the contents published in the group on their personal walls, but only vice versa, as such content makes sense in that context only ${ }^{12}$. These dynamics, reminiscent of the old chat rooms, are suited to a group of subjects united by the same strong passion. They are very involved in it, very active in the community, and only relatively interested in opening the circle and letting new members in. That is why cucinaremale has remained mainly a Facebook group, even when a dedicated fanpage (fb.com/cucinaremale.original) and an official website (cucinaremale.it) were launched. Or when its cult status was altered by unforeseen publicity.

\section{The cucinaremale hopeless cooks club goes viral}

On 10 October 2014, "la Repubblica", one of the leading newspapers in Italy, created one of its online clickbait-galleries, entitled Il club dei cuochi negati: 'Fieri dei nostri piatti falliti' ("The club of hopeless cooks: Proud of our failed dishes") ${ }^{13}$, out of 29 pictures selected among the hundreds posted on the group's wall. The very next day, the gallery was posted on

\footnotetext{
${ }^{11}$ For the notion of spreadability, see Jenkins, Ford, and Green (2013).

${ }^{12}$ Gathering people from all over Italy, as well as Italians abroad and foreigners living in Italy (sono la giapponese che abita in italia da sei anni, "I am the Japanese woman who has been living in Italy for six years now"), it has to be noted that the group has organized a series of social dinners in different cities, to let the members physically meet: Vi prego organizziamo un raduno \#cucinaremale, ognuno porta qualcosa, poi buttiamo tutto nella pattumiera e andiamo a mangiare al ristorante!! ("Please, let's organize a \#cucinaremale gathering, everyone brings something, then we throw everything in the trash can and go eat at the restaurant!").

${ }^{13}$ https://www.repubblica.it/cronaca/2014/10/10/foto/piatti_inservibili-97836791/1/?ref= fbpr (accessed 10 February 2020).
} 
Facebook ${ }^{14}$, so that it quickly became a viral phenomenon that lasted for a few weeks. The group started growing rapidly in size. It counted about 1,400 members before the exposure and just two days later it had almost doubled by 1,200 additional members. As has already happened with other Facebook groups or pages (for example, Il coinquilino di merda, "The shitty roommate", fb.com/ilcoinquilinodim, created in October 2012), the endorsement by "la Repubblica" gave the start to the popularization of the $X$-male ("X-badly") format. A series of similar, copycat, and subsidiary pages started sprouting like mushrooms over the Italian Facebook. A parasitic page Lo chef universitario di merda ("The shitty university student chef") was created on 11th October 2014, blatantly stealing the group's symbol (the "chicken à la Stephen King", cf. infra) for its cover image. Groups like Cucinare Peggio ("Cooking Worse"), arredaremale ("furnishingbadly"), giardinaremale ("gardeningbadly"), campeggiaremale ("campingbadly"), and conoscersimale ("meetingbadly") sprang out directly from the cucinaremale wall, by applying the very same formula patented by the badcooks to areas of human experience other than cooking.

All this unexpected success led to a series of issues only partially managed by the administrators and the community. New members to cucinaremale had always shown an inability to grasp the spirit of the group at first but, after the group went viral, trolls, as well as users posting culinary masterpieces or suggesting online resources and giving advice aimed at improving other members' cooking abilities, became a common sub-genre of their own:

Propongo il boicottaggio. Si boicotta la coca cola, si boicotta il trentino, si boicotta Israele.. è ora che anche noi boicottiamo chi ci propina piatti succulenti e gustosi!! Non rispondiamo ai loro post, anzi quando spuntano con la loro odiosa premessa 'non odiatemi', ignoriamoli e commentiamo tutti i polli della [nome dell'utente X], i tortelli informi del [nome dell'utente Y], il principe Rana della [nome dell'utente Z], tutte le muffe e gli avambracci abbrustoliti cosi da affossare le tortine con i fiorellini e le braciole cotte alla perfezione! Uniamoci compagni!!

I propose a boycott. Everybody boycotts Coca-Cola, boycotts Trentino [a region of Italy], boycotts Israel.. it is time we too should boycott whoever foists succulent and tasty dishes on us!! Let's not respond to their posts, even when they pop up with their hateful premise 'don't hate me', let's ignore them and keep on commenting on all [name

\footnotetext{
${ }^{14}$ https://www.facebook.com/Repubblica/posts/10152784743036151 (accessed 10 February 2020).
} 
of member X]'s chickens, [name of member Y]'s shapeless tortelli, [name of member Z]'s Frog Prince, all the moulds and the burnt forearms so as to put down the flowery cakes and the perfectly cooked chops! Let's unite comrades!!

The widening of the community also multiplied the cases of censorship - scarcely attested before - aimed at avoiding offence to vegetarians, vegans, and animal rights activists' sensibilities. In October 2014, a member posted two pictures of a whole kidgoat's head, a typical festive meal in some Sicilian towns (Fig. 2). After a very long debate (which one may better describe as a "shit-storm" flame, in social media jargon), the pictures were judged pointlessly cruel and then removed, while their author decided polemically to leave the group. Posts with similar imagery were later published by other users but the contents, although debated, were not eventually deleted ${ }^{15}$. Even a community programmatically dealing with food which is "bad", "non-edible" etc. by definition (since it is cooked poorly, badly), seems to having established certain boundaries. Some food is disgusting but is good to be posted, some other is not: especially, the kind of food which does not anesthetize its cadaveric nature.

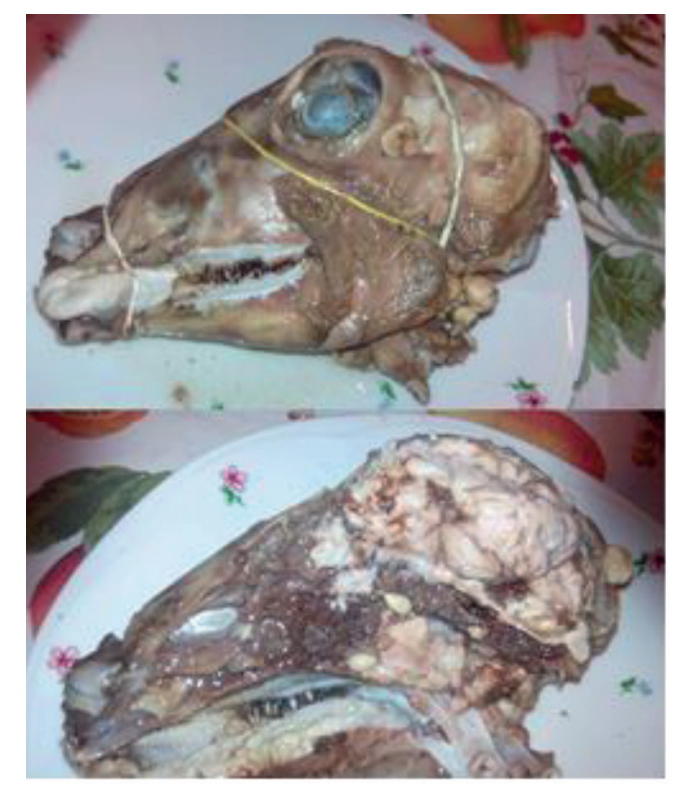

Fig. 2: Pictures of a kidgoat's head posted in October 2014. The post with the two pictures was deleted shortly thereafter.

${ }_{15} \mathrm{~A}$ case in point is available at https:/www.facebook.com/groups/cucinaremale/ permalink/362730540553033/ (27 October 2014, accessed 10 February 2020). 


\section{I can do worse: the cucinaremale competition}

Albeit communitarian and supportive, each and every badcook is still participating in a challenge and is trying to win it (con gli spaghettini Gotam voglio preparare un pastone che manco Poison Ivy..., "with the Gotam noodles I want to prepare a mash that not even Poison Ivy [could]...”), even at the cost of cheating (cioè si cucina dimmerda apposta, "that is cooking like shit on purpose"). Whereas cooking competitions are won by the competitor who creates the best dish, the perfect dish, or at least the dish that meets certain criteria (ingredients, cooking times, presentation etc.), here the praises abound for those who post the worst demonstration of their own bad cooking, aware that, strange as it may seem, an already disastrous dish can always be made even worse. Posts displaying expired or rotten food are forbidden by policy and their authors risk expulsion. Despite this, mouldy, oxidized, petrified, mummified foods are on the group's agenda.

Cioè raga, dato l'esponenziale numero di post, che ultimamente leggo e che vedo, sugli alimenti scaduti, cé qualcuno che bara. [...] Adesso per onestà intellet[t]uale, bisognerebbe dare una prova concreta che il cibo sia veramente scaduto, postare in aggiu[n] ta almeno una tarma, una formica. E che cavolo, girano tante bufale in giro!

I mean guys, given the exponential number of posts, that I've read and seen lately, about expired food, someone is cheating. [...] Now as a matter of intellectual honesty, the authors should give concrete proof that the food has really expired, they should also post a moth, an ant. What the heck, there are so many hoaxes around!

Industrial, packaged, ready-made, and generic food (filetto strapazzato di...boh, un pesce, "scrambled fillet of...dunno, a fish") are the norm. This contrasts with the emphasis on the raw material that is one of the pivotal topoi of the culinary discourse, where food is always specified and detailed (as "natural", "fresh", "genuine", "organic", "traditional", "high quality", "100\% Italian", "harvested by hand" "from the field to the plate", "free-range", "wild" etc.): Magari cuciniamo male, ma la roba almeno è fresca......da frigo ("Maybe we cook badly, but the stuff is at least fresh ... from the fridge").

If the jury of members does not judge the dish as sufficiently ugly, its creator receives a playful threat of expulsion (ma questo non è cucinaremale, sembra buono, baaaaaan!, "but this is not badcooking, it seems good, baaaaaan!"). Sometimes the authors themselves trigger the threat - sono migliorata, lascio il gruppo ("I've improved, I'm leaving the group"). 


\section{Cooking degree zero: cucinaremale or no cooking at all}

The badcooks mostly describe themselves as workers (parents and workers) and students (generally, university students). They do not want to cook because they do not have the time to do so: Dopo 13 ore in ufficio è bello tornare a casa e trovare questo [un frigo vuoto].... The valley of death and shadows ma soprattutto shadows ("After 13 hours in the office it's nice to come home and find this [an empty fridge] .... The valley of death and shadows but above all shadows"); In tempi di studio non si può mica perdere tempo ai fornelli, quindi ci si affida alla nouvelle cuisine express [introducendo un pasticcio di avanzi tirati fuori dal frigorifero] ("When it's study-time you can't waste time cooking, so you rely on express nouvelle cuisine [introducing a hash of leftovers pulled out of the refrigerator]").

The work/time isotopy is central to the average badcook. There are plenty of pictures from lunch breaks where the sad and solitary meal, devoted to a rigid pauperism (they are piatti mainagioia, "never-a-joy dishes, dishes without any joy"), is shown being consumed at the desk, in front of the computer. It is a triumph of makeshift sandwiches, microwave soups and instant pasta, lunchboxes filled with a few leaves of green salad, and dishes of difficult decipherability. It is the triumph of routine - a quite different routine from that pursued by the metrosexual person, namely the single man with courteous manners and attention to detail, completely committed to an "anti-domestic" ideal and the "cult of fire" (where food is always "scalded", "sautéed", "browned”, "grilled” etc.; see Pozzato ivi: 149-166).

The badcooks are guided by a having-to-do that they cannot escape from (they have to feed themselves and their families). However, they are certainly not guided by a wanting-to-do modality. Their interest in food is exclusively practical, limited to the mere satisfaction of bodily needs, possibly in the most economical way (not only in terms of material and economic but also temporal factors). Cooking is a duty, a necessity in fact, not a pleasure. To those who say "cooking relaxes me", the unmotivated, tired, dysphoric, always-in-a-hurry badcooks reply "eating relaxes me" or "you cook, then". The perfect recipe our unwilling cooks are looking for is one of the facile facile ("easy-peasy") type: Prendete dal frigo tutto ciò che sta per andare in putrefazione, tagliate la metà marcia e [mettete] il resto in padella con olio ("Take everything that is rotting in the fridge, cut the rotten half and [put] the rest into the pan with oil"). This is the frittata alla $f^{*} c k$ that shit principle ("omelette $\dot{a}$ la $\mathrm{f}^{\star} \mathrm{ck}$ that shit"). The badcooks are not really "looking for" a recipe, they just open the fridge and grab what is left inside, 
the first available thing, more or less usable ${ }^{16}$. Then, it suffices to prendere $e$ frullare tutto ("take and blend everything"). Anything to avoid ending up burning another hard-boiled egg.

Ingredients, meaning the basic constituents of a recipe, tend to disappear, and only food remains, or rather industrial food (Althea, Bo Frost, Carrefour, Conad, Coop, Fileni, Findus, Heinz, Knorr, Lutosa): ready for consumption (canned and packaged), semi-processed (pre-cooked, frozen), flavouring (mayonnaise, soy sauce, cream). Food means discomfort, uneasiness, and shame. The slices of ham or cheese, the farfalle, fusilli or panzerotti - types of pasta - from the day before all retain on their surface the shape of the plastic containers in which they were stored until a few moments before being photographed. We can almost feel their turgid, gelatinous, plastic, woody, soft, or stringy consistency, depending on the case. Eating the ready-to-eat packaged salad of the supermarket è come [ $\mathrm{m}]$ angiare quella paglietta di plastica per riempire i cesti di natale ("is like [e] ating the plastic straw used to fill Christmas baskets").

By misappropriating Roland Barthes' notion (1947), we may define this logic of food (non-)preparation as "cooking degree zero". A raw, cold cooking, a food bricolage/do-it-yourself that takes place far from the cookers and the ovens; a partly desperate, partly amused cut \& paste and mix of food. We do not even access the culinary domain, we stop at a gastronomic level which is all reducible to the alimentary one, because cucino cosi male... che non cucino ("I cook so badly...that I do not cook at all"). Thus, a meal can consist of a sliced red onion with some bread, four raw sausages lined up on a plate, a glass of sugared water. At the intersection of food junk and junk food, we may find more daring variants too: a banana sandwich with ketchup, a slice of melon with canned tuna (il prosciutto [crudo] si e il tonno no?, "[cured] ham is fine and tuna is not?"), a brioche stuffed with an ice-cream biscuit, some biscuits spread with Sicilian pesto.

\section{La grande bouffe (boueuse ou brûlé): cucinaremale galore}

The badcooks who do not embrace the "degree zero" style are actually often guided by a strong wanting-to-do modality. They want to cook (sabato prossimo sarà il compleanno di mia figlia e volevo fare tutto io; "next Saturday

\footnotetext{
${ }^{16}$ It may be interesting to compare our badcooks with the freegans, namely those who practice the critical recovery of wasted food. Whereas the latter rummage through scraps and waste in search of good food destined for destruction, the former are reckless, uncritical, as they often keep food that should no longer be consumed in their fridge, and do not discard it, but rather consume it (or, at least, they try to).
} 
will be my daughter's birthday and I want to do everything myself") and they do cook. However, they cannot, they are not able to, they do not know how to do it, and they know it: Allora, gli ingredienti buoni buonini ci sono [delle fettine di filetto]. L'idea è la pizzaiola. Come la rovino? ("Good-goodie ingredients, checked [some slices of fillet]. The idea is pizzaiola. How do I make sure to ruin it?"). They are keen but they still lack cooking knowledge. They do not know where to put what or how (ho scoperto che le uova non vanno nel microonde, "I discovered that eggs are not supposed to be microwaved", reads a comment to the picture of a disintegrated egg), ending in confusing or overturning the alimentary syntagms (a pre-cooked cutlet becomes the side dish to an egg with a tomato). One can:

Fare il tiramisù coi savoiardi senza glutine e non accorgersi che, appunto,sono diversi dai savoiardi classici. Già il fatto che non si ammorbidivano nel caffé mi avrebbe dovuto far sospettare che forse non andavano bene, ma imperterrita ho continuato.É venuto fuori una specie di sanpietrino al cacao da tagliare col seghetto.Sigh.

Make tiramisu with gluten-free ladyfingers, without realizing that they are very different from the classic ones. The fact they did not soften when soaked in coffee should have made me suspect they were not suitable, but I undauntedly went on. The result was a kind of rock hard cocoa-flavoured slab that needed cutting with a saw. Sigh.

Vi ho pensato oggi quando, dopo aver creato per la prima volta la mia palletta di pasta frolla, averla messa in frigo a riposare, esser andata a lavare l'attrezzatura usata, ho visto con orrore che nella ciotola della bilancia c'era una montagnetta di zucchero rimasta li sola soletta e abbandonata.

I thought about you today when, after having created my little ball of shortcrust pastry for the first time, after having put it into the fridge to rest, after having washed all the equipment, I noticed with horror the little heap of sugar that had remained all alone and abandoned in a bowl on the scale.

These cooks lack the cook's know-how. They are inattentive (Vorrei condividere con voi la mia opera d'arte: 'La distrazione'. Dovevano essere delle cipolle in agrodolce; "I would like to share my work of art with you: 'Distraction'. They were supposed to be sweet and sour onions"). They do not use the right tools (many pictures show fishes whose heads or tails overflow from the pan), they use them but with discouraging results (Oggi sono riuscita a scuocere il risotto con il bimby, "Today I managed to overcook risotto 
with the Bimby"; Non mi è riuscita la pasta sfoglia. Col bimby, "I failed the puff pastry. Using the Bimby"), or they directly destroy them (Bimby aside, one of the few images specifically dedicated to a kitchen tool is a semi-carbonized ladle). They do not even have the basics: non ho sale, non ho limone ("I don't have salt, or lemon"); ho finito lo zucchero ("I ran out of sugar"). They do not have the cook's eye, nor the eye of the gourmet, nor of the foodie: Il secondo [segreto di questa ricetta] è il colore del piatto, che deve essere nero e fa tanto 'ricercato' e 'stile' ("The second [secret of this recipe] is the colour of the plate, which has to be black and gives it such an 'elegant' and 'stylish' feel").

Such inexperience and unpreparedness not only have culinary but also physical consequences. While cooking the badcooks burn and cut themselves in a blaze of blood splashes and bandages that may even have led to - involuntary - self-cannibalism. One of our very badcook reports that they once cut a portion of their middle finger which dropped directly into the frying pan and was crispy deep fried.

\section{Tell me what you eat (Because I cannot figure it out): The badcooks as detectives}

Whereas the "degree zero" badcooks are equipped with a not-wanting-to-do modality that becomes a wanting-not-to-do one, the wannabe try-harder cooks do nothing but borrow the forms of a more extensive, more intrusive, "pretentious" duty than mere subsistence. Not only do they cook, but - subjected to the gastromaniac Zeitgeist - they cook elaborate recipes: delicacies, roasted meats, fresh and stuffed pastas, risottos, creams, cakes, pies etc. All of them no longer "home-made", but rather "wrongmade". The result is binge-gone-wrong. So that we are faced with tortured, torn, and charred surfaces, worthy of a last dinner in Pompeii. We witness muddy mashes and abnormal masses rebelling against their creator just like Frankenstein's monster. This food is more similar to architectural materials, organic concretions, or humors than to real food. A cream cake reminds one of the intonaco rustico per villetta di campagna ("the raw plaster for country house"); a lentil soup looks like catrame ("tar"); and for one's debut post one can choose to show la torta salata uscita un po['] a forma $d i . .$. ("the flan that looks a bit like..."), later known as the infamous tortaculo ("ass cake").

The once-edible matter that constitutes the badcooks' dishes is underor over-processed, there is no middle ground. The food is raw or burnt, too greasy, too wishy-washy or, on the contrary, too dry. The output of the process resembles an interrupted recipe or, on the contrary, a bolus, an 
already partially metabolized meal. Either way, the food is unrecognizable: Trovo sublime che il primo commento alle foto postate qui sia in realtà una domanda, LA domanda: 'cosee?' ('It's sublime that the first comment to the photos posted here is actually a question, THE question: 'what is it?"'); $m a$ è già vomitato, no? ("you already threw it up, didn't you?"). The results differ from their inspirational models so much that the most suitable way to present them is the Expectation vs. Reality meme template.

Just like the taster, the assayer, or the osphresiologist, the member of cucinaremale must be something of an investigator. When viewers are not explicitly asked to guess (the cosèe? "what is it?" + picture is an established trope), the members include the revelation of what they are cooking or have cooked in the story of the plate or in the description of the photo, often in the form of a punch line: Sono dei muffin. Ovviamente con la giusta dose di fantasia ("These are muffins. Obviously with the right dose of imagination").

\section{The chicken à la Stephen King - the cucinaremale poster-recipe}

The meat dishes posted in cucinaremale are rarely featured with that obliteration of the dead body and, therefore, that anaesthetization of the death of the animal to which we have been accustomed for decades. By definition, this is one of the main characteristics of food porn, whose images "always repress the process of production of a meal" (Coward ibid.), in order to magnify the final result, the final presentation.

Many cucinaremale pictures display what we may define as "cadaverous courses". The "piranha" used by "la Repubblica" as the cover image to its gallery fits the definition, as well as the picture that became a true manifesto and non plus ultra model. It attained 780 likes and about 460 comments in a couple of months, developing a second narrative, an internal epic, and a meta-discourse within the group (also after it had been automatically removed when its author closed down their Facebook account). I am talking about the pollo alla Stephen King ("chicken à la Stephen King"), as it was immediately renamed by the community; the definitive culinary horror.

The description reads: Era il 2009 e volevo sorprendere i miei invitati alla cena di Halloween. Ci riuscii, ma saltarono la portata di carne ("It was 2009 and I wanted to surprise my guests at the Halloween dinner. I succeeded, but they skipped the meat course"). The picture shows a whole chicken, complete with skin, comb, beak, legs, semi-raw in the thighs, semi-burnt in the head, from whose back an egg with a cracked shell emerges along with some sprigs of rosemary. Placed on large leaves of lettuce (fresh and raw, inserted, as a garnish, at the end of cooking), the chicken's body lies inside 
an encrusted pan, without any baking paper or aluminium foil (see Fig. 3). The recipe is revealed in a comment by its author:

Eliminate le interiora, bruciacchiare tutta la superficie per eliminare piumette e la pelle dura delle zampe. Date una prima cottura in padella con pochi odori (non sia mai ad esagerare con queste finezze). Poi mettetelo in forno con un uovo nel concuimisiedo per ultimare la cottura.

Take out the entrails, burn the entire surface to eliminate the feathers and the hard skin of the legs. Give a first cooking in the pan with some aromas (never exaggerate with these sophistications). Then put it in the oven with an egg in its bottom [lit. "that-on-which-I-sit"] to finish the cooking.

The crowd shouts out:

Capolavoro ("Masterpiece"). Credo di non aver mai visto nulla di più disgustoso. Complimenti davvero! ("I don't think I've ever seen anything more disgusting. Sincere congratulations!"). Questa per me dovrebbe essere l'immagine del gruppo... Riassume benissimo il senso del nostro essere qui! Medaglia d'oro ("This should be the image of the group ... It summarizes the sense of our being here! Gold medal"). Lo dico con la morte nel QVORE: [...] questo gruppo non ha più senso. Basta. Fine. Schluss. Ogni cosa postata da altri non sarà nemmeno lontanamente paragonabile ("I say this with death in my HART [the misspelling is in the original text, since quore is a phonetic writing for cuore, "heart"]: [...] this group no longer makes sense. That's enough. The end. Schluss ["Closing" in German]. Anything posted by others will not even be remotely comparable"). È una delle cose più belle e terribili mai concepite, bisognerebbe dedicargli ogni piazza o via di fronte a una rosticceria. Per me questo 31 ottobre torna tipo Pet Semetary per chiederti l'anima piuttosto che dolcetto o scherzetto ("It is one of the most beautiful and terrible things ever conceived, we should dedicate to it every square or street in front of a rotisserie. For me this $31^{\text {st }}$ of October will return in Pet Semetary fashion to ask for your soul rather than trick or treat"). Sappi che hai reso mia figlia vegetariana (era qui con me) ("You should know that you have turned my daughter into a vegetarian (she was here with me)").

The picture presents prominent horror-like traits and the users have associated it, commenting by posting pictures themselves, with long series of visual nightmares crystallized in the collective imagery. A deconstructionist intertextual web is being woven. We go from the infernal creatures filling Hieronymus Bosch's paintings, to the Tyrannosaurus Rex of Jurassic Park, from H. R. Giger's Alien, to the creature in David Lynch's Eraserhead 
and P.H. Barnum's Fiji Mermaid. The poor chicken becomes a Moloch, the Antichrist, Satan, against which the intervention of exorcist Father Amorth is invoked (Questo [...] non è cucinaremale, questo è cucinare IL male; "This [...] is not evilcooking, this is cooking EVIL itself”). It is compared to the shrunken mummy of Ramses II and is worthy of a "B movie by Corman" or a "Troma masterpiece, 'Poultrygeist, Night of the chicken dead". Maybe it is an effect made for a film by Lucio Fulci, or a torture designed for $A$ Clockwork Orange. Perhaps it is a case for Mulder and Scully's X-Files, or a visual translation of Sepultura's Death Embryonic Cells. The author herself compared it to Nightmare's Freddy Krueger.

An unrecognizable ("but ... but ... what animal is it?") and grotesque ("but how did the corpse - I mean, the doll — resist the attempt to cook it?") figure, looked upon with resentment by Grumpy Cat and with amused horror by Italian TV host Gerry Scotti (both in the form of memes), the "Stephen King chicken" is scandalous and obscene, it breaks the taboos, it shows what should not be shown: è che fa impressione pensare che la carne che mangiamo un tempo sia stata parte di un animale. davvero i polli non nascono già pronti per il forno? ("it is disgusting to think that the meat we eat was once part of an animal. Are chickens really not born all ready for the oven?"); francamente io ti avrei denunciato alla protezione animali... $e$ cavolo, metti una stellina per censurare i genitali! siamo mica su playboy! ("frankly I would have reported you to animal protection... damn, put a star to censor the genitals! We're not on Playboy!”).

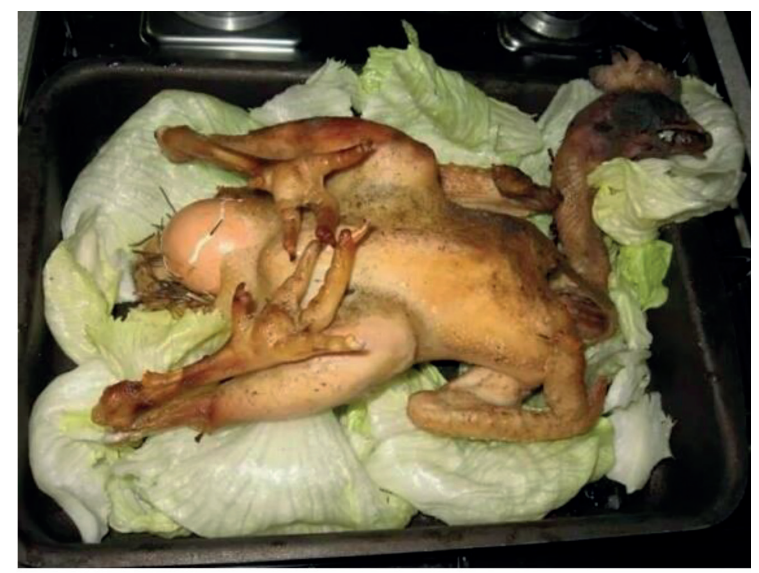

Fig. 3: The "chicken à la Stephen King", posted on 13 September 2014; now unavailable, since its author has taken down their Facebook account (the original URL was https://www.facebook.com/photo.php?fbid=10152773916483128). 
The egg in particular seems to have triggered the curiosity of the badcooks (ci siamo soffermati tutti sulluovo nel c..o; "we all focused on the egg in the a. s"), as if it were a strange vilification of a corpse. The members wonder about the origins of such slaughter: No ma scusate, non ha senso l'uovo dentro. E parte della scena: Lo ha partorito mentre agonizzava a 200 gradi! ("Sorry guys, but the egg inside does not make sense. It has to be part of the scene: [the chicken] gave birth to it while it was agonizing at 392 degrees!”).

\section{The art of food (de)composition: The badcooks as badphotogra- phers}

If "presentation is everything", almost all the pictures published in cucinaremale represent a full-bodied "nothing" that stands as the perfect anti-manual of food porn principles. When glamour photography is applied to food and cooking, the image is capable of synaesthetically communicating inviting perfumes, soft and crunchy textures, surprising flavours; in other words, delicious and tempting foods. Food styling does so also by "cheating", namely by modifying the appearance of food to the detriment of its actual flavour and even edibility. Food stylists use hair dryers to make the surface of a dish look crunchy, put cardboard inside a slice of cake to give it consistency and geometricity. On the contrary, every component of the badcooks' photographs participates in the same lack of know-how which is at the basis of the recipes, both the sad and the ambitious ones (as regards ingredients, preparation, presentation, conservation etc.).

The profilmic material is what it is. Let us quickly analyse the other components of typical cucinaremale photography. The shot is badly taken: it is partial, it flattens the image, or it creates daring perspectives which monstrously deform the dish. The photograph is blurred, the light is too intense or too dim, the colours are livid. Given all this, given the cadaveric isotopy, some pictures eerily recall Mantegna's Lamentation of Christ. If food porn hyperrealism makes one think of a glamorous Norman Rockwell, cucinaremale expressionism reconnects to David Cronenberg's "new flesh" nightmares. Whereas the food porn high-definition mise en scène makes mouths water, the low-resolution foods of cucinaremale destroy the appetite. Even when the taste would perhaps deserve a chance.

In fact, it is possible that some of these ugly foods were actually good, but it is difficult to escape from the associative-connotative chain according to which "beautiful" (on the side of the signifier) is "good" (on that of the signified) and "ugly" is "bad": Secondo me non sono male ma nessuno li vuole quantomeno assaggiare. (sono biscotti) ("I think they are not bad 
but nobody even wants to give them a try. (they are cookies)"). Above all, cucinaremale is certainly a matter of "bad presentation" (of "bad enunciation", in semiotic terms), not necessarily of "bad eating". One can, for instance, cucinaremale ma mangiarebene ("cookbadly but eat well"), genuinely: nessun cibo è stato realmente cotto da me [, sono] verdure surgelate in busta e lenticchie in scatola ("no food was really cooked by me [, they are] frozen vegetables and canned lentils"). A picture can portray some fresh berries, although sembra un po' il cervello spappolato di uno zombie ("it looks like the mashed brain of a zombie") or quella cosa che non si può dire ("that thing that cannot be named").

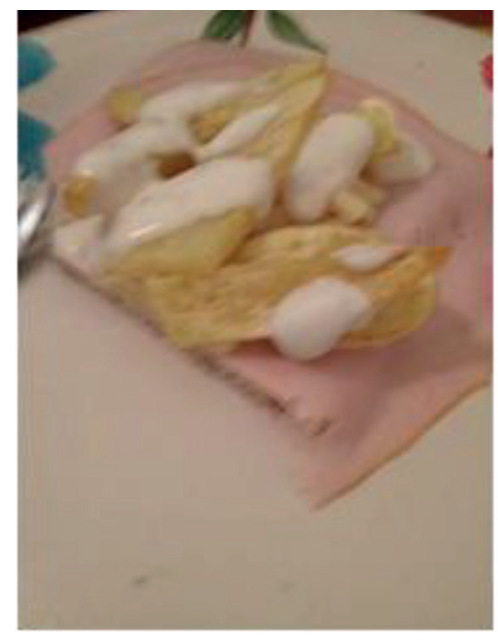

Fig. 4: Picture imitating the cucinaremale way of photographing food. Originally created in October 2014 , the picture was posted in cucinaremale on 7 June 2018, receiving "mixed reviews" (available at https://www.facebook.com/photo. php?fbid=10216008383593232)

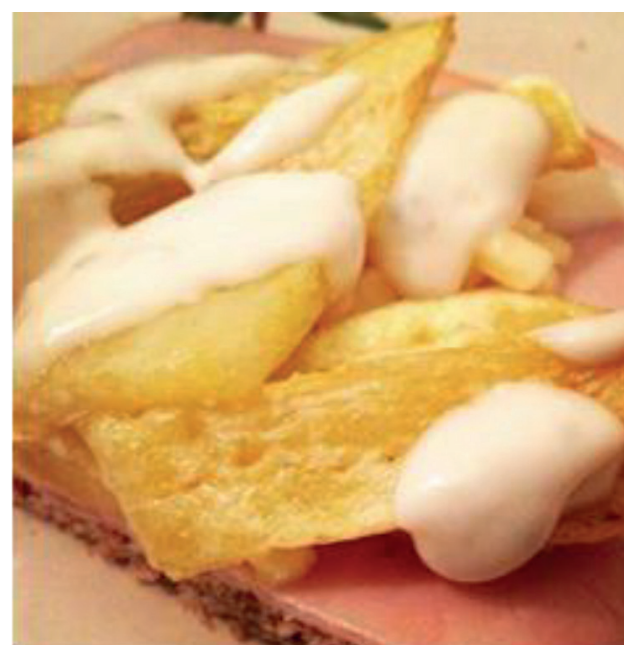

Fig. 5: Picture imitating the food porn approach. Posted on 30 November 2018 (available at https://www.facebook.com/groups/ cucinaremale/permalink/1092180130941400/)

In 2014, when I discovered the group, I did a little personal experiment. I created two different pictures starting from the very same elements and composition: wholemeal toast, roasted turkey breast, cheese cuts, Greek sauce (all of them being industrial food), and fried potatoes (from the garden). I took one photo according to the canons of the cucinaremale food aesthetics (see Fig. 4) and the other in food porn fashion (see Fig. 5). I intended to post the two pictures, at different moments, onto the wall of the group, but I never did so at the time. I eventually posted one of them - the apocryphal cucinaremale - on 7 June 2018. I received wonderful 
comments that made it possible for me to reconstruct the entire scenario of implicated aesthetics and values: Cucina male, scrive male, fotografa peggio.. per me può diventare amministratore ("He cooks badly, he writes badly, he photographs worse.. in my opinion he can become admin"); Questa per me è alta cucina. Manca giusto qualche salsina, ma per il resto è la perfezione assoluta, fatta cena [triplo emoji che ride piangendo] ("For me this is haute cuisine. Only some sauces are missing, but for the rest it is absolute perfection, dinner made [triple laughing-crying emoji]"); Cose fatte palesemente per racimolare likes e sprecare cibo. Well done ("Things clearly made only to collect likes and waste food. Well done"). One user gave me a diesci (for dieci, "ten"; a reference to the connoted pronunciation of TV host and chef Alessandro Borghese, which became a meme over several Italian Facebook groups). Many users recognized my playful allusion to vaporwave aesthetics, as I used a noted vaporwave text editor (lingojam.com) to change the font of the text. I posted the second picture some time later (30 November 2018). The foodie style was immediately recognized as such, the meal was unanimously judged as mouthwatering, so that almost all commentators invoked the ban (questo non è cucinaremale!, "this is not cookingbadly!").

\section{Good irony is the best seasoning: cucinaremale's humour and parodies}

Irony - self-irony, indeed - is the right key to access the world of cucinaremale. The badcooks are aware of their wanting-not-to-do or notbeing-able-to-do. It is precisely upon this awareness that the whole community has grounded the wanting-to-laugh and wanting-to-make-laugh at the heart of the group's discourses and practices. Conscious that food discourse is more a matter of words than of food, the badcooks take on the role of the great chef, describing their own creations so that the most disastrous recipes are punctiliously exposed. A grilled chicken breast with mushrooms and peppers, partially scorched and covered with soy sauce, is introduced in macaronic French: pett de poll avec funghi et peperoni, tout tagliè e cott insiem sour la piastrà et avec salsà de soià, naturelment. Oui, c'est bon. The terminology follows the style of avant-garde cuisine: a pile of ricotta cheese becomes a "destructured cassata [a typical Sicilian specialty]". The badcooks call each other "Maestro".

The parody serves the irony and the ludic effort is concentrated over a series of polemical totems. Such figures are playfully deprecated in order to suggest that, whereas the badcooks do cook badly, others, albeit in disguise, are playing a very similar game as well. A newspaper clipping posted onto the group's wall shows the infamous, once-viral recipe of pollo alla piastra 
di Elisabetta Canalis ("Elisabetta Canalis' grilled chicken" - she is a noted Italian TV personality), a perfectly fitting case of "cooking degree zero", in spite of the food porn-ish style of the picture. The recipe reads: Prendete una fetta di petto di pollo e mettetela su una piastra o su una padella ben calda. Quando il colore della carne diventa bianco, la pietanza è pronta ("Take a slice of chicken breast and place it on a grill or in a very hot pan. When the colour of the meat turns white, the dish is ready").

A photo of some packaged fettuccine sponsored by a funeral agency has been posted. The "Stephen King chicken" recipe has been commented on by making a parallel with the famous pollo in crosta di sale ("salt-crusted chicken") by Giallo Zafferano, the leading Italian food blog. In reality, the recipes are not too different, both of them including the scandalous "ass egg". Do-it-yourself demotivationals and memes have been created, like the one displaying this dialogue between two kids: Anche a casa vostra dite le preghiere prima di mangiare? ("At home, do you pray before eating too?"). No, mia mamma cucina bene.... ("No, my mom cooks well"). Members wonder if the new Japanese trend of preparing food inserted in a condom or exotic penis-shaped seafood may be considered examples of cucinaremale. Badcooks make jokes to mock and yet shield one another: Pranzo: riso integrale della camargue scaduto e non abbastanza cotto misto a sgombro in scatola che manco il gatto, bestia intelligente, ha volute. Solo voi potete capirmi ("Lunch: expired Camargue brown rice, not sufficiently cooked, with canned mackerel, that not even the cat, smart beast, wanted. Only you can understand me"); La coca dice che ce la farò ("Coke says I can do it") is the caption to a picture with some quartered, semi-carbonised frankfurters and a bottle of Coca-Cola Zero with the text "I will survive" printed on the label. Stock phrases are parodied, stereotypes are pointed out, and political issues peep out; commenting on a photo portraying media tycoon and right-wing politician Silvio Berlusconi with a "royal cake" a member says:

QUANDO C'ERA LUI LA GENTE cucinavabene!

Torta a dir poco regale con tanto di corona e scettro di pasta di zucchero dove la compagna Francesca Pascale ha fatto scrivere: 'A te che sei il Re dei nostri sogni, buon compleanno Presidente'

WHEN HE WAS HERE PEOPLE cookedwell!

A royal cake, to say the least, with a crown and a scepter in sugar paste where his partner Francesca Pascale had the [pastrychef] write: 'To you who are the King of our dreams, happy birthday President' 
It has to be noted that the expression quando c'era lui is an allusion to the popular saying by nostalgic supporters of fascism, referring to Benito Mussolini.

The group's humour and lively wit has produced a whole series of parody book titles and covers. Most of them do not make sense for the non-Italian speaker, due to phonetically motivated puns. I will list them all without translation and focus on three of them that make sense also to the English speaker:

CuOceano male, La solitudine dei tuberi primi, L’uomo che sussurrava ai taralli, Le camole che non ti ho detto, Tre metri sotto il cellophane, Cinquanta sfumature di gricia ("Fifty Shades of Gricia"; a typical Roman pasta), Il passato [di verdure] è una terra straniera, Quer pasticciaccio brutto de pappa toscana, L'uovo senza qualità, Nessuno si salverà da sodo, Il silenzio degli ingredienti, Il burro oltre la siepe, Un [piatto a forma di] cuore cosi in bianco, Lorigine delle spezie ("The Origin of the Spices"), Cent'anni di olitudine, Dei delitti e delle penne, La mortazza incantata, I dolori del giovane Wuber ("The Sorrows of Young Wuber"; a famous brand of frankfurters).

\section{Cacograstomania: The cucinaremale upside-down food valoriza- tion}

cucinaremale is a journey Through the looking glass of the contemporary food craze where "ugly" becomes "beautiful" and insults become compliments: non riesco più a distinguere un complimento da un rimprovero ("I can no longer distinguish a compliment from a rebuke") says the creator of the Frankenchicken. A post from a member reads: siete un manuale di cattive pratiche culinarie[.] da antropologa mi sento come Alice nel paese delle meraviglie, vi assaggerei tutti (metaforicamente)! ("you are a manual of culinary bad practices [.] As an anthropologist I feel like Alice in Wonderland, I would taste you all (metaphorically!").

The pictures of cucinaremale are ugly per se, as pieces of organic matter, and formally ugly, due to the imbalance in the visual composition, and yet they are transformed into ugly-with-a-purpose, a playful and artistic ugliness (Eco 2007: 19). A certain degree of aesthetic attitude is admitted indeed, but only so much and, preferably, in an ironic fashion. Despite the ingeniously funny compositions by a user who re-created in a cucinaremale fashion works of art such as Leonardo's Vitruvian Man (see Fig. 6) or Munch's Scream, a post dated 13 October $2014^{17}$, a true ode to the group,

\footnotetext{
${ }^{17}$ Originally at https://www.facebook.com/groups/cucinaremale/permalink/35714182444 $5238 /$.
} 
was deleted on the grounds that it constituted a mere display of eloquence and an intellectualization, namely a distortion, of the spirit and aims of the group. No country for posh old badcooks.

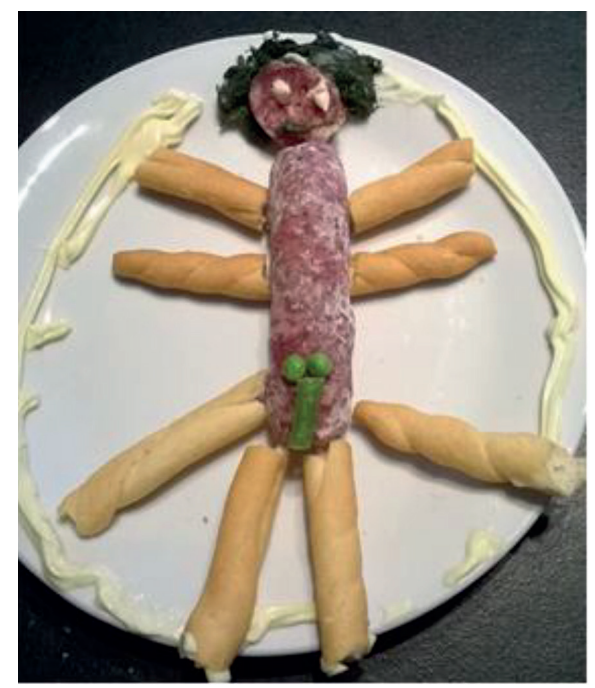

Fig. 6: Leonardo's Vitruvian Man in the food style of cucinaremale, posted on 16th December 2016 (available at https://www.facebook.com/photo. php?fbid=10209597389029407, accessed 10 February 2020).

To sum it up, we face a reversed, belly-up gastromania, whose axiology has been infernally inverted: a cacogastromania, a gastrotoxia. In a world of experts, chefs, gourmets, foodies, and food stylists, this Facebook group owned by the badcooks stands as the Masada of a minority, joyfully and proudly oppositional, a counter-cultural trend: sono contraria [a rendere il gruppo privato]. sennò come fanno i miei contatti a sapere che faccio parte di unélite? ("I'm against [turning the group into a private one]. otherwise how would my contacts get to know that I am part of an élite group?"). An ephemeral outpost of re-appropriation and re-territorialization of food by sloppiness and failure, cucinaremale proposes the realism of "everyday life" and "normality".

This valorization of food overturns the hegemonies: the practical (postfoods such as Soylent), the critical (freegans), the ludic-aesthetical (foodpornies, junkfoodies), and the utopian-existential (gourmets, foodies, vegans). It does so in the name of a knowing-to-be and of a meta-knowledge paradoxically grounded in will: a negative (the wanting-not-to-do of the "cooking degree zero") or positive one (the wanting-to-do of the "big muddy or burned binges"). Modalized and pathemized in such a way, the 
badcooks affirm and accept their own nature, their own being. So that a badcook can proclaim:

NOI NON DOBBIAMO VERGOGNARCI DI CIO' CHE SIAMO. Dobbiamo essere orgogliosi. [...] In ogni nostro piatto, cè della passione, cè dellemozione. C’è il nostro disagio raccontato al mondo, cè la nostra interiorità espressa e ciò che di bello e brutto muove il nostro animo. La cucina è arte e questo è il nostro personalissimo mondo. In ogni nostro piatto noi esprimiamo ciò che siamo. Quindi perché vergognarsi? Amiamoci tutti.

WE MUST NOT BE ASHAMED OF WHAT WE ARE. We must be proud. [...] In all our dishes, there is passion, there is emotion. There is our discomfort told to the world, there is our expressed interiority and all the beautiful and ugly things that drive our soul. Cooking is art and this is our very personal world. In every dish we express what we are. So why be ashamed? Let's all love one another.

\section{References}

Barthes, R. 1947. "Le degré zéro de lécriture". Combat, 1er août.

Coward, R. 1984. Female Desire: Women's Sexuality Today. London: Paladin.

Eco, U. (ed.). 2007. Storia della bruttezza. Milano: Bompiani.

Fiorentini, I. 2013. "ZOMG! Dis iz a New Language: the Case of Lolspeak". Newcastle Working Papers in Linguistics Vol. 19, No. 1, 90-108.

Genette, Gérard. 1972. Figures III. Paris: Éditions du Seuil.

Honigman, B. 2017. The 100 Most Popular Hashtags on Instagram. Huffington Post, 24 May 2017. Available at: https://www.huffingtonpost.com/brian-honigman/the-100-most-popular-hash_b_2463195.html (accessed 10 February 2020).

Jacobson, M. F. 1972. Eater's Digest: The Consumer's Fact-Book of Food Additives. Garden City NY: Doubleday \& Company Inc.

Jenkins, H., S. Ford and J. Green. 2013. Spreadable Media: Creating Value and Meaning in a Networked Culture. New York: New York University Press.

Lévi-Strauss, C. 1964. Le Cru et le Cuit. Paris: Plon.

Mangiapane, F. 2015. L'invenzione della cucina Nordica. In Lexia. Rivista di semiotica, 19-20. Ariccia: Aracne editrice, 153-165. 
Marino, G. 2015. "Semiotics of Spreadability: A Systematic Approach to Internet Memes and Virality". Punctum Vol. 1, No. 1, 43-66. Available at: https:// punctum.gr/112-2/semiotics-of-spreadability-a-systematic-approach-to-internet-memes-and-virality/ (accessed 10 February 2020).

Marrone, G. 2014. Gastromania. Milano: Bompiani.

Pozzato, M. P. 2012. Foto di matrimonio e altri saggi. Milano: Bompiani.

Stano, S. 2016. “Introduction: Semiotics of Food”. Semiotica, No. 211. 19-26. 